
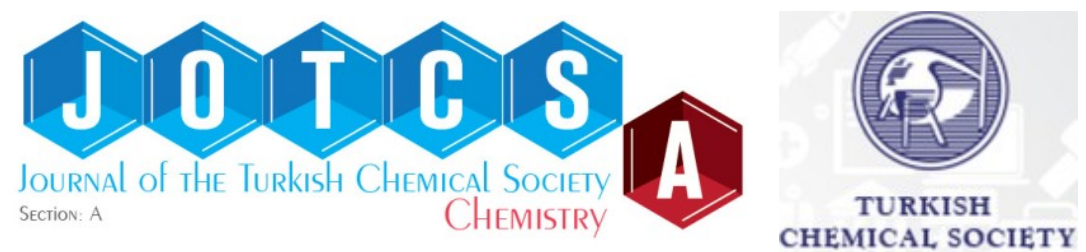

\title{
Synthesis of Isatin and its Derivatives Containing Heterocyclic Compounds
}

\author{
Pratibha Mishra (D), Arunesh K. Mishra (D), Anil. K. Bahe (D), Atish Roy \\ and Ratnesh Das* \\ Department of Chemistry, Dr. Harisingh Gour Central University, Sagar- 470003 (M.P.), INDIA
}

\begin{abstract}
Isatin or $1 \mathrm{H}$-indole-2,3-dione or 2,3-dioxindole is an indole derivative. Isatin and its analogs are synthetically useful substances where they may be utilized for the production of a broad range of heterocyclic molecules, which are depicting a wide reach of biological and pharmacological activities, as well as anticancer, anti-inflammatory, antiviral, anticonvulsant, antiTB, antidiabetic, anti-microbial, antitumor, antimalarial, anti-HIV, antibacterial, anti-analgesic, and antiplasmodial activities. Isatin is a precursor for many synthesized therapeutic molecules that are amenable to pharmacological action and have excellent biological potential. Isatin has a magnificent scaffold for both the natural and synthetic construction of molecules. These molecules are being used in drug therapy such as anticancer, antibiotic, and antidepressant drugs and have many more clinical applications. Due to its privileged scaffolding, the synthetic versatility of isatin has produced many structurally diverse derivatives, including the substitution of mono-, di- and trisubstitution of the aryl rings A and those derived by derivation of isatin nitrogen and C2 and C3 carbon moieties. As a result, improving and expediting access to isatin-related molecules is a challenging study in synthetic organic chemistry.
\end{abstract}

Keywords: Isatin, $1 \mathrm{H}$-indole-2,3-dione, heterocyclic compounds, anticancer, anti-inflammatory, antimalaria, anti-HIV, drug therapy.

Submitted: July 04, 2021. Accepted: September 22, 2021.

Cite this: Mishra P, Mishra A, Bahe A, Roy A, Das R. Synthesis of Isatin and its Derivatives Containing Heterocyclic Compounds. JOTCSA. 2021;8(4):1089-98.

DOI: https://doi.org/10.18596/jotcsa.962260.

*Corresponding author. E-mail: ratneshdas1@gmail.com.

\section{INTRODUCTION}

Isatin derivatives (1H-indole-2,3-dione) are among the most important heterocyclic compounds currently occupying an essential place in pharmaceuticals and chemicals $(1,2)$. Isatin, also known as indole quinine and indenedione, is a biologically active compound with a wide range of properties. Isatin has two cyclic rings in its structure, one of which is six-membered (aromatic property) and the other is five-membered (antiaromatic character). Both rings lie in the same plane, a five-membered ring contains a nitrogen atom and two carbonyl groups. Isatin was first synthesized in 1840 by Erdmann and Laurent as an oxidation product of the indigo dye by nitric acid and chromic acid, which resulted in isatin's bright orange-colored monoclinic crystals product (3). Kekulé established isatin's present form, and the chemistry of isatins was initially studied by Sumpter and then revised by Popp and Silva et al.<smiles>O=C1Nc2ccccc2C1=O</smiles>

Isatin

Figure 1: Chemical structure of Isatin.

Typically, isatin is found in the plant of the Isatis genus (4) in Calanthe stain LINDL.(5) and Couroupita guianensis Aubl. (6) and discharges 
from the parotid organ of the bufo frog $(7,8)$ and in people as it is a metabolic subsidiary of adrenaline (9). Different subbed isatin have likewise been distinguished in plants, for example, methoxy phenylmethyl isatin acquired from Melochia tomentosa $(10,11)$, hydroxylated isatins disengaged from Streptomyces (fungi)(12), and marine mollusks (13), where they are proposed to assume a guarded part against pathogenic creatures. Isatin is additionally discovered to be a part of coal tar (14).<smiles>COC(CCCCc1ccccc1)N1C(=O)C(=O)c2ccccc21</smiles>

methoxy phenylpentyl isatin<smiles>C=C(c1ccc2c(c1)NC(=O)C2=O)C(C)C</smiles>

6-(3'-methylbuten2'-yl) isatin<smiles>C=C(c1ccc2c(c1)C(=O)C(=O)N2)C(C)C</smiles>

\section{5-(3'-methyl buten2'-yl) isatin}

Figure 2: Structures of methoxyphenylpentyl isatin, 6-(3'-methylbuten $\left.2^{\prime}-\mathrm{yl}\right)$ isatin and 5-(3'methylbuten $\left.2^{\prime}-y \mathrm{l}\right)$ isatin.

A thorough investigation of the manufacture and response of isatin, a compound with an indole motif, a ketone, and a - lactam moiety, revealed many intriguing chemical reactions and processes. Isatins' unique capacity to act as both an electrophile and a nucleophile and their wide distribution has made them important building blocks in organic synthesis. Syntheses of several heterocyclic structures of biological importance, such as indoles, $\beta$-lactams, pyrrolidine, quinolones and 2-oxindoles, etc. Literature survey revealed that isatin derivatives such as hydrazine, mannich bases, Schiff bases, and spiroindolinones possesses an extensive range of biological activities such as antimicrobial (15), antitumor (16), antimalarial (17), anti-HIV (18), analgesic, antibacterial (19), anti-inflammatory (20), antiglycation (21), neuroprotective (22), antioxidant (23), anti-tubercular (24), antifungal (25), anticonvulsant (26), antidepressant (27), anticancer $(28,29)$, antiplasmodial activity (30), anti-corrosive (31), antiepileptic (32), antidiabetic (7) and antiviral (33) antianxiety (34), and antiasthma (35). In 1965, an isatin-2,3-dionebased compound Metisazone was developed, it is an antiviral agent used against viral infections as a prophylactic agent (36). Food and Drug Administration, USA (FDA) approved an isatin derivative Sunitinib maleate to treat different malignancies such as advanced renal-cell carcinoma, pancreatic neuroendocrine tumors and gastrointestinal stromal tumors $(37,38)$.<smiles>CN1C(=O)/C(=N/NC(N)=S)c2ccccc21</smiles>

Metisazone<smiles>CCN(CC)CCNC(=O)c1c(C)[nH]c(/C=C2\C(=O)Nc3ccc(F)cc32)c1C</smiles>

Sunitinib

Figure 3: Structure of Metisazone and Sunitinib.

\section{GENERAL METHODS FOR SYNTHESIS OF ISATINS}

\section{Metalation of Anilide Isatin Compound}

A new strategy for creating isatin includes orthometalation (DoM) of $\mathrm{N}$-pivaloyl-and $\mathrm{N}$-(tbutoxycarbonyl)- anilines is presented. The dianions are treated with diethyl oxalate after deprotection and cyclization of the middle of the 
road a-ketoesters, and isatins are created (Scheme 1). This technique for orchestrating 4-subbed isatins from meta-subbed anilines has the advantage of being regioselective (39).

\section{Martinet's Isatin Synthesis}

Isatin was made by responding a fragrant amino atom with an oxomalonate ester or its hydrate within sight of a corrosive to frame a 3-(3hydroxy-2-oxindole) carboxylic corrosive subsidiary, which was then oxidatively decarboxylated to yield isatin (Scheme 2)(40).

\section{Stolle's Isatin Synthesis}

The Stolle isatin synthesis involves reacting anilines by oxalyl chloride to generate a chlorooxalylanilide intermediate, which is subsequently cyclized in a Lewis acid, commonly $\mathrm{BF}_{3}, \mathrm{Et}_{2} \mathrm{O}$, or aluminum chloride. However, $\mathrm{TiCl}_{4}$ has been used as well (41).

\section{Sandmeyer's Isatin Synthesis}

Isatin was made by combining aniline with chloral hydrate and hydroxylamine hydrochloride in aqueous sodium sulfate to generate an isonitrosoacetanilide, which was then separated following treatment with concentrated sulfuric acid to obtain $>75$ percent isatin (42).

\section{Gassman's Isatin Synthesis}

This procedure starts with creating an intermediate 3-methylthio-2-oxindole, which is then oxidized to produce substituted isatin (40-81 percent yield) (41).<smiles>CN(C(=O)O)c1c[R]ccc1</smiles>

methyl(phenyl)carbamic acid<smiles>CCOC(=O)C(=O)c1[R](I)cccc1N(C)C(=O)O</smiles>

(2-(2-ethoxy-2-oxoacetyl) phenyl)(methyl)carbamic acid<smiles>O=C1Nc2ccccc2C1=O</smiles>

indoline-2,3-dione

Scheme 1: Metalation of anilide isatin synthesis. Adapted from (39).

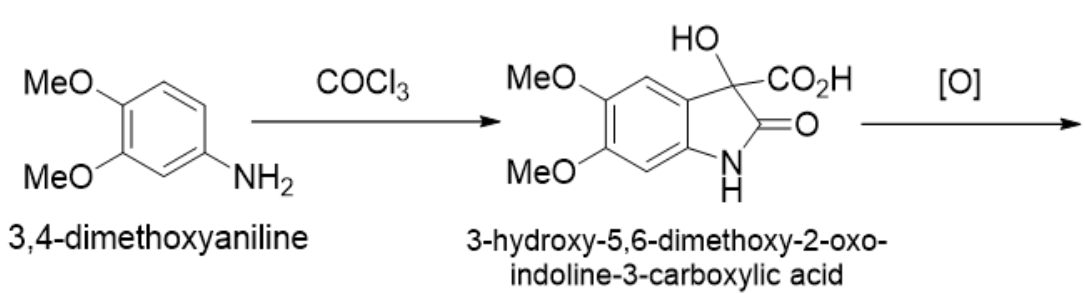

Scheme 2: Martinet's isatin synthesis. Adapted from (40).<smiles>COc1cccc(OC)c1OC</smiles>

\section{1,2,3-trimethoxybenzene}<smiles>CC(C)(C)[Mg][Mg]</smiles>

6,7-dimethoxyindoline-2,3-dione

Scheme 3: Stolle's isatin synthesis. Adapted from (41).

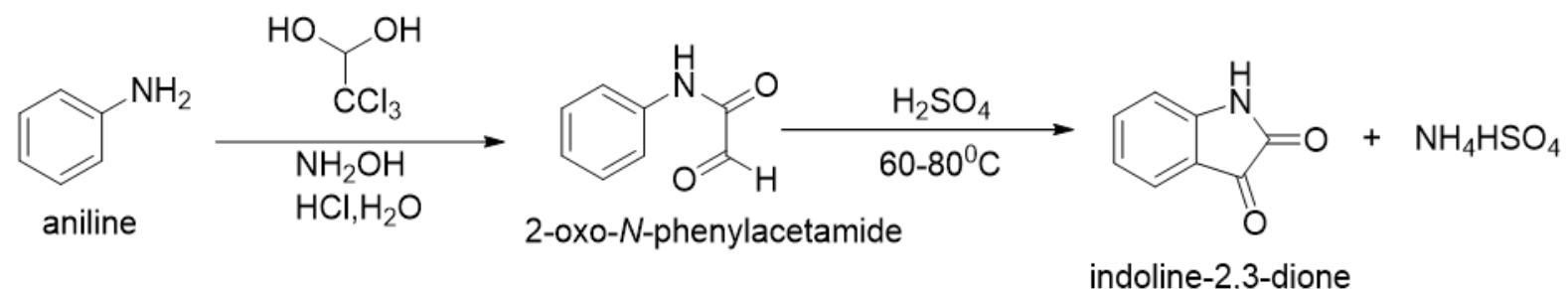

Scheme 4: Sandmeyer's isatin synthesis. Adapted from (42). 


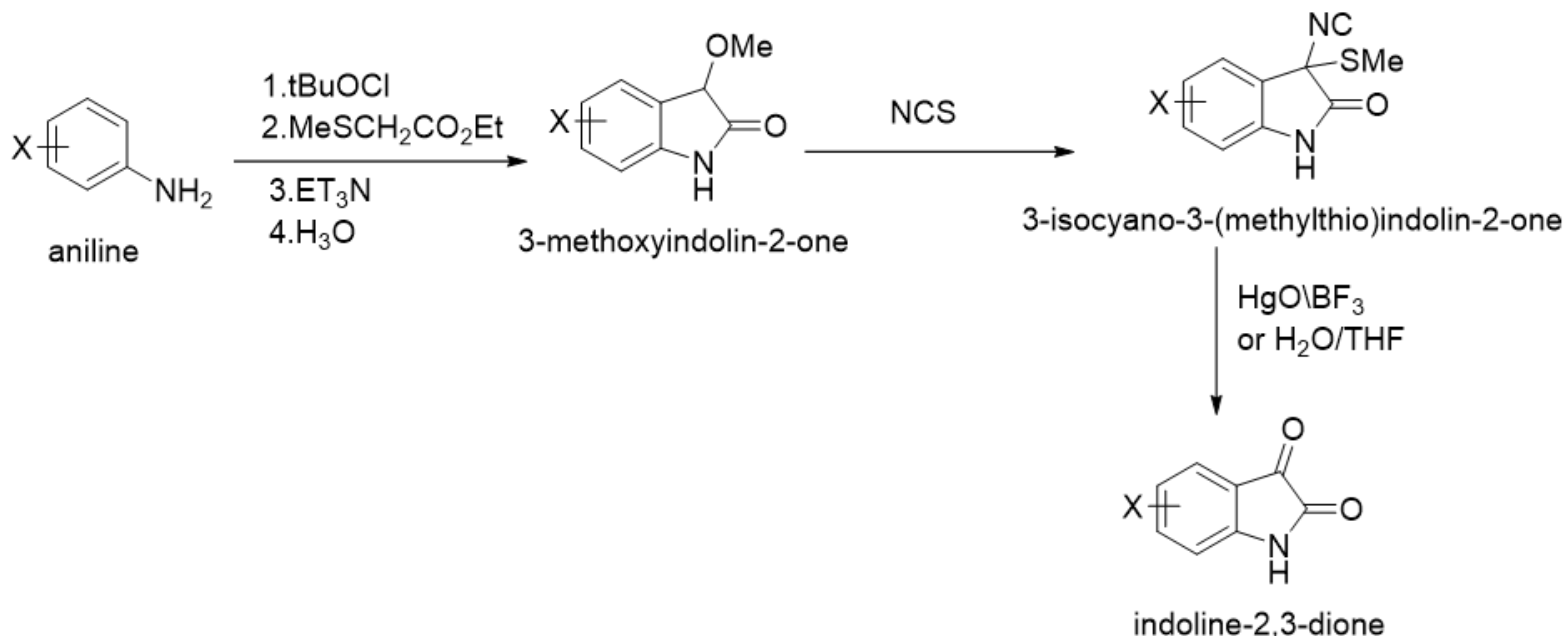

Scheme 5: Gassman's isatin synthesis. Adapted from (41).

To complete the synthesis of $\mathrm{N}$-substituted isatins, several new synthetic methods have been devised. One such endeavor uses $\mathrm{I}_{2}$-DMSO as a catalyst in a metal-free synthesis Scheme 6 . The technique involves activating the $\mathrm{C}-\mathrm{H}$ bond and then internal cyclizing 2- amino acetophenones to make $\mathrm{N}$ alkylated and $\mathrm{N}$-arylated isatins (43).<smiles>[R]Nc1ccc([R2])cc1C(C)=O</smiles>

2-amino acetophenones<smiles>[R2]c1ccc2c(c1)C(=O)C(=O)N2[R]</smiles>

$\mathrm{N}$ - alkylated isatin

$$
\begin{aligned}
& \mathrm{R}_{1}=\mathrm{H}, \mathrm{Me} \text {, allyi, Et, Bn, 4-MeOBn, 4-ClBn, 4-FBn } \\
& \mathrm{R}_{2}=\mathrm{H}, \mathrm{Cl}, \mathrm{Me}
\end{aligned}
$$

Scheme 6: Combination of $\mathrm{N}$-alkylated isatin subsidiaries from 2-amino acetophenones. Adapted from

Indole, NBS, and anhyd. DMSO mixture were taken in a 3-necked R.B. flask that was clean and dry. The flask was heated to $60{ }^{\circ} \mathrm{C}$ for 6 hours under decreased pressure and $80{ }^{\circ} \mathrm{C}$ for 16 hours. After the reaction was finished, the mixture was placed in water, and the extracts were extracted with dichloromethane. The sections were then dried over $\mathrm{MgSO}_{4}$ and purified using silica gel chromatography with DCM as the eluent M.P.202 ${ }^{\circ} \mathrm{C}$ (Scheme 7)(44).

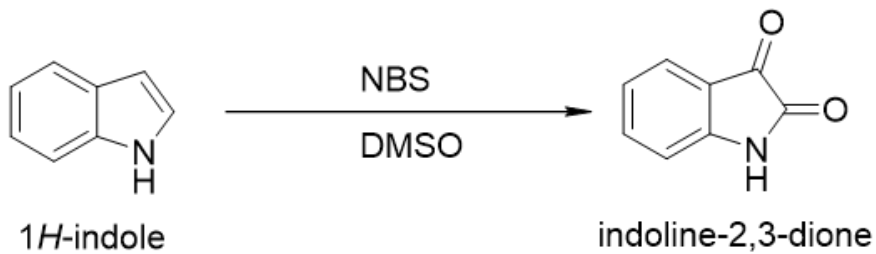

Scheme 7: Blend of isatin. Adapted from (44).

The reaction was carried out by dropping a solution of isatin, con. $\mathrm{H}_{2} \mathrm{SO}_{4}$, into a solution of at 0 to $5^{\circ} \mathrm{C}$ for 1 hour, yielding 5- nitroisatin. 249-250 ${ }^{\circ} \mathrm{C}$ M.P.
Isatin is nitrated at $\mathrm{C}-5$ with $\mathrm{KNO}_{3}$, in the presence of $\mathrm{H}_{2} \mathrm{SO}_{4}$. (Scheme 8)(44). 


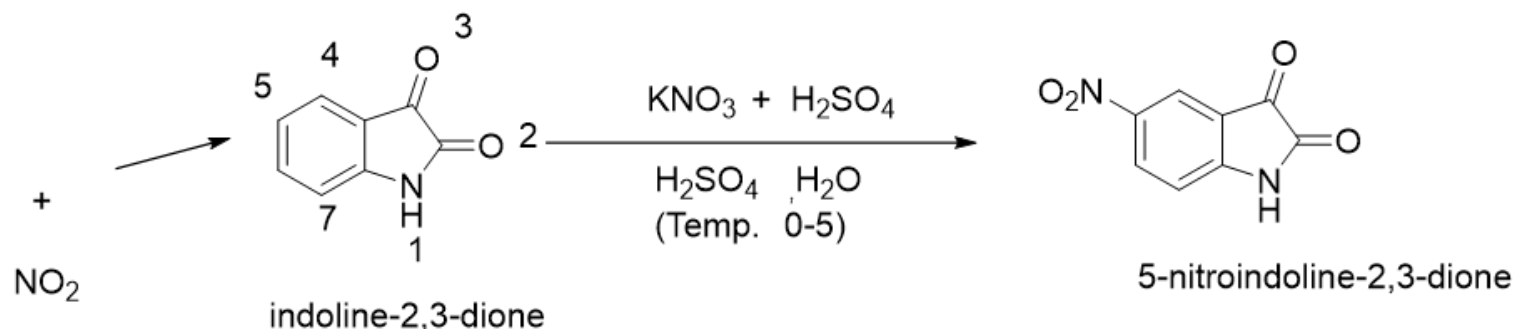

Scheme 8: Synthesis of 5-nitro-1H-indole-2,3-dione. Adapted from (44).

On reaction with chloral hydrate and isonitrosoacetanilides gave equivalent indolin-2, 3hydroxylamine hydrochloride, diones after reaction with sulfuric acid (Scheme 9) isonitrosoacetanilides were produced from (45). substituted anilines. Substituted

$$
\underset{\mathrm{NH}_{2} \mathrm{OH} . \mathrm{HCl}}{\stackrel{\mathrm{Cl}_{3} \mathrm{CCH}(\mathrm{OH})_{2}}{\longrightarrow}}
$$

\footnotetext{
(E)-2-(hydroxyimino)- $N$-(p-tolyl)acetamide
}

Aniline

Scheme 9: Isonitrosoacetanilides have been synthesized from substituted anilines on reaction with chloral hydrate and hydroxylamine hydrochloride (45).

Isatins are made by responding a sweet-smelling amino atom with an oxomalonate ester or its hydrate within sight of a corrosive to create a 3(3-hydroxy-2-oxindole) carboxylic corrosive subsidiary, which is along these lines oxidatively decarboxylated to give the ideal isatin (Scheme 10)(46).<smiles>COc1ccc(N)cc1OC</smiles>

3,4-dimethoxyaniline

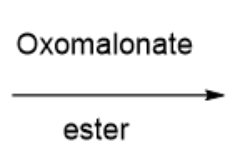<smiles>COc1cc2c(cc1OC)C(O)(C(=O)O)C(=O)N2</smiles><smiles>O=CCO</smiles>

3-hydroxy-5,6-dimethoxy-2-oxoindoline-3-carboxylic acid

Scheme 10: Isatins are created when one aromatic amino molecule reacts with another aromatic amino molecule. Adapted from (46).

The related (2-oxo-1,2-dihydro-3H-indol-3ylidene)malononitriles, the Knoevenagel condensation products, are obtained by grinding isatins with malononitrile for 15 minutes at room temperature in the presence of $1-5$ equivalent of water (Scheme 11)(47).
Under ultrasonic irradiation, 3-(indol-3-yl)-3hydroxyindolin-2-ones were synthesized from isatins and indoles using $\mathrm{Fe}(\mathrm{III})$ as a recyclable homogeneous catalyst (Scheme 12). It was discovered that the circumstances used resulted in 85-95 percent yields (48). 
<smiles>[R2]c1ccc2c(c1)C(=O)C(=O)N2</smiles>

1 af<smiles>N#CCC#N</smiles>

malononitrile

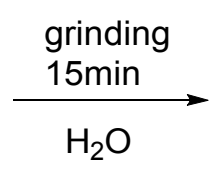

r.t.<smiles>[R2]c1ccc2c(c1)C(=C(C#N)C#N)C(=O)N2[R]</smiles>

2af

$$
\begin{aligned}
& \text { a } R^{1}=R^{2}=H \\
& b R^{1}=M e, R^{2}=H \\
& c R^{1}=E t, R^{2}=H
\end{aligned}
$$

Scheme 11: Synthesis of isatines with malononitrile via Knoevenagel condensation. Adapted from (47).<smiles>c1ccc2[nH]ccc2c1</smiles>

$1 H$-indole<smiles>O=C1Nc2ccccc2C1=O</smiles>

indoline-2,3-dione

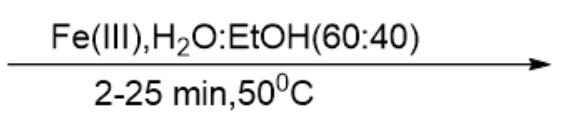<smiles>O=C1Nc2ccccc2C1(O)c1c[nH]c2ccccc12</smiles>

3-hydroxy-3-(1H-indol-3-yl)indolin-2-one

Scheme 12: Ultrasound-advanced, Fe(III)-catalyzed 3-indolylation of isatins. Adapted from (48).

The electrocatalytic change of isatins and barbituric acids in ethanol in a unified cell within sight of sodium produces subbed 5,5'- (2-oxo-2,3-dihydro$1 \mathrm{H}$-indole-3,3-diyl) bis (pyrimidine-2,4,6(- $1 \mathrm{H}, 3 \mathrm{H}$ $5 \mathrm{H}$ )- triones (B) with 89-95 percent substance yields and 89-95 percent current yields (Scheme
13). This novel and effective synergist strategy is fundamental because of its variety situated massive scope activities. It is an illustration of an electrocatalytic double response that is simple and biologically amicable (49).<smiles>[R2]NCC(=O)N(C)/C=C1\C(=O)N([R])c2ccc3ccccc3c21</smiles>

(Z)-2-amino- $N$-((2-oxo-2,3-dihydro-1H-benzo [e]indol-1-ylidene)methyl)acetamide

(A)<smiles></smiles>

(Z)-2-amino-N'-(2-oxoindolin-3-ylidene)acetohydrazide

(B)

Scheme 13: Isatin and barbituric acids are used to make a functionalized (2-oxo-2,3-dihydro-1H-indole3,3-diyl) bis (pyrimidine) system. Adapted from (49).

The response of isatins to nitromethane/nitroethane in the presence of $1,4-$ diazabicyclo[2.2.2] octane (DABCO)(50) has been described as an efficient and universal technique for the production of 3-hydroxy-3-(nitromethyl)indolin-2-one (C). The reaction is catalytic and swift; yields are incredibly high, and no solvents are used. 


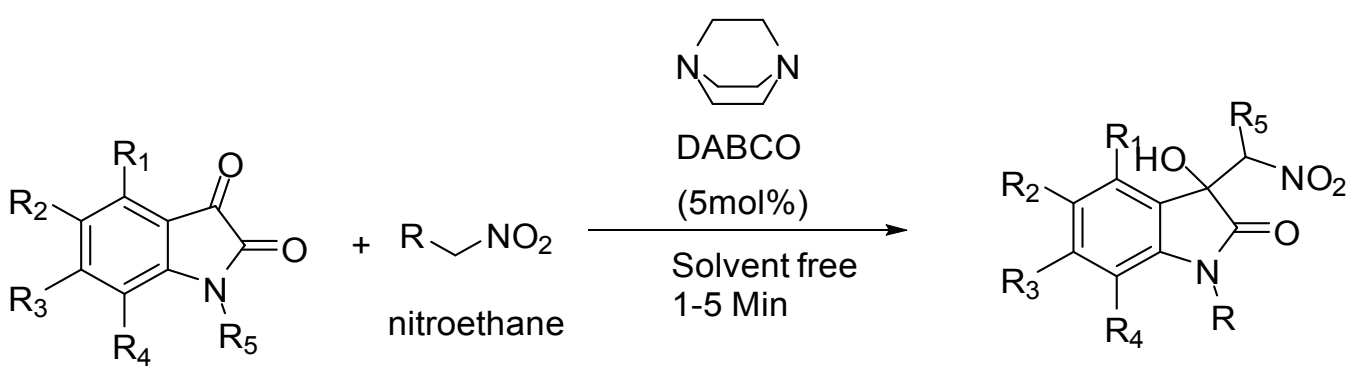

2,3 di-one indolin

(A)
(B) 3-hydroxy-3-(nitromethyl)-indolin-2-one

$\mathrm{R}=\mathrm{H}, \mathrm{CH} 3, \mathrm{Bn}$

$\mathrm{R} 1=\mathrm{R} 2=\mathrm{R} 3=\mathrm{R} 4=\mathrm{H}, 5-\mathrm{CH} 3,5-\mathrm{Cl}, 5-\mathrm{Br}, 5-1,5-\mathrm{NO} 2,5-\mathrm{OCF} 3$

$\mathrm{R} 5=\mathrm{H}, \mathrm{CH} 3$

1,4 diazabicyclo[2,2,2]octane(DABCO)

Scheme 14: 3-Formation of hydroxy-(nitromethyl) indolin-2-one derivatives utilizing DABCO as a catalyst. Adapted from (50).

By basically refluxing a response mixture of several types of isatins and heterocyclic ketene aminals (HKAs) with acetic acid, a straightforward and practical approach for synthesizing highly substituted imidazopyrroloquinoline derivatives was devised (Scheme 15). In drug discovery, this method is appropriate for both combinatorial and equal blends (51).<smiles>[R][R1]1nc(-c2ccc([R3])cc2)c2n1C(=O)c1c-2c(-c2ccc([R])cc2)nc2ccc([R])cc12</smiles>

(A)

$\mathrm{R} 1=\mathrm{H}, \mathrm{Br}, \mathrm{Cl}, \mathrm{F}$

$\mathrm{n}=1,2,3$;

$\mathrm{R} 2=\mathrm{H}, \mathrm{CH} 3$

$\mathrm{R} 3=\mathrm{CH} 3 \mathrm{O}, \mathrm{CH} 3, \mathrm{H}, \mathrm{Cl}$

6-phenyl-8H-imidazo[1',2':1,2]pyrrolo [3,4-c]quinolin-11(9H)-one derivatives $78-94 \%$

Scheme 15: Imidazopyrroloquinoline compounds with extensively modified substituents were synthesized. Adapted from (51).

\section{CONCLUSIONS}

Isatin is a heterocyclic compound that is vital for the blend of natural mixtures. Schiff bases of isatin, 3,3-disubstituted oxindoles, and spirooxindoles are a portion of the remarkable frameworks that might be created utilizing isatin as an antecedent material. They can function as electrophilic partners in many of the traditional aldehyde transformations, such as the production of 1,3-dipoles, the Knoevenagel reaction, and so on. On the other side, isatins have a sensitivity that is not seen in aldehydes, including ringopening processes. The majority of these compounds also have biological and pharmacological characteristics. In recent times, isatin has also been extensively used to produce a variety of chemical compounds.

\section{REFERENCES}

1. Prudhomme M. Advances in Anticancer Agents in Medicinal Chemistry. [Internet]. Sharjah:

Bentham Science Publishers; 2013 [cited 2021 Sep 24]. $\leq U R L>$.

2. Cândido-Bacani $P$ de $M$, Reis $M B$ dos, Serpeloni JM, Calvo TR, Vilegas W, Varanda EA, et al. Mutagenicity and genotoxicity of isatin in mammalian cells in vivo. Mutation

Research/Genetic Toxicology and Environmental Mutagenesis. 2011 Feb;719(1-2):47-51. 
3. Silva JFM da, Garden SJ, Pinto AC. The chemistry of isatins: a review from 1975 to 1999. J Braz Chem Soc. 2001 Jun;12(3):273-324. <DOI>.

4. Borad MA, Bhoi MN, Prajapati NP, Patel HD. Review of Synthesis of Multispiro Heterocyclic Compounds from Isatin. Synthetic Communications. 2014 Apr 18;44(8):1043-57. $<$ DOI $>$.

5. Ramakrishna Reddy K, Mahendra K. N. Synthesis of 3-[(Z)-5-Amino-1, 3, 3-trimethyl cyclohexyl methylimino]-1, 3-dihydroindol-2-one as a novel Schiff base. Molbank. 2006 Dec $1 ; 2006(6)$ : M517. <DOI>.

6. Singh GS, Desta ZY. Isatins As Privileged Molecules in Design and Synthesis of Spiro-Fused Cyclic Frameworks. Chem Rev. 2012 Nov 14;112(11):6104-55. <DOI>.

7. Varun V, Sonam S, Kakkar R. Isatin and its derivatives: a survey of recent syntheses, reactions, and applications. Med Chem Commun. 2019;10(3):351-68. <DOI>.

8. Khan FA, Maalik A. Advances in Pharmacology of Isatin and its Derivatives: A Review. Trop J Pharm Res. 2015 Nov 6;14(10):1937. <DOI.

9. Chiyanzu I, Hansell E, Gut J, Rosenthal PJ, McKerrow JH, Chibale K. Synthesis and evaluation of isatins and thiosemicarbazone derivatives against cruzain, falcipain-2 and rhodesain. Bioorganic \& Medicinal Chemistry Letters. 2003 Oct; 13(20):3527-30. <DOI .

10. Ali R, Gilani A-H, Choudhary M, Aftab K, Sener $B$, Turkoz S. Isolation of Antihypertensive Alkaloids from the Rhizomes of Veratrum album. Planta Med. 1993 Dec;59(06):569-71. <DOI>.

11. Kapadia GJ, Shukla YN, Basak SP, Sokoloski EA, Fales HM. The melosatins-a novel class of alkaloids from melochia tomentosa. Tetrahedron. 1980 Jan;36(17):2441-7. <DOI>.

12. Shaaban KA, Shaaban M, Nair V, Schuhmann I, Win HY, Lei $L$, et al. Structure elucidation and synthesis of hydroxylated isatins from Streptomycetes. Zeitschrift für Naturforschung B. 2016 Dec 1;71(12):1191-8. <DOI>.

13. Benkendorff K, Bremner J, Davis A. Indole Derivatives from the Egg Masses of Muricid Molluscs. Molecules. 2001 Jan 16;6(12):70-8. $\leq$ DOI $>$.

14. Mamedova $\mathrm{YV}$, Hasanova $\mathrm{AE}$, Gasimova $\mathrm{SZ}$, Huseynova RA, Mamedov IG. Some isatin based synthesis. New Materials, Compounds and Applications. 2020;4(1):16-9.

15. Kumar M, Ramasamy K, Mani V, Mishra RK, Majeed ABA, Clercq ED, et al. Synthesis, antimicrobial, anticancer, antiviral evaluation and QSAR studies of 4-(1-aryl-2-oxo-1,2-dihydro-indol3-ylideneamino)-N-substituted benzene sulfonamides. Arabian Journal of Chemistry. 2014 Sep;7(4):396-408. <DOI>.

16. Havrylyuk D, Zimenkovsky B, Vasylenko O, Gzella A, Lesyk R. Synthesis of New 4-

Thiazolidinone-, Pyrazoline-, and Isatin-Based Conjugates with Promising Antitumor Activity. J Med Chem. 2012 Oct 25;55(20):8630-41. <DOI>.

17. Raj R, Singh P, Singh P, Gut J, Rosenthal PJ, Kumar $\mathrm{V}$. Azide-alkyne cycloaddition en route to 1 $\mathrm{H}$-1,2,3-triazole-tethered 7-chloroquinoline-isatin chimeras: Synthesis and antimalarial evaluation. European Journal of Medicinal Chemistry. 2013 Apr;62:590-6. <DOI .

18. Paul BK, Ray D, Guchhait N. Unraveling the binding interaction and kinetics of a prospective anti-HIV drug with a model transport protein: results and challenges. Phys Chem Chem Phys. 2013;15(4):1275-87. <DOI>.

19. Kiran G, Maneshwar T, Rajeshwar $Y$, Sarangapani M. Microwave-Assisted Synthesis, Characterization, Antimicrobial and Antioxidant Activity of Some New Isatin Derivatives. Journal of Chemistry. 2013;2013:1-7. <DOI .

20. Prakash CR, Raja S, Saravanan G. Design and synthesis of 4-(1-(4-chlorobenzyl)-2,3dioxoindolin-5-yl)-1-(4-substituted/unsubstituted benzylidene) semicarbazide: Novel agents with analgesic, anti-inflammatory and ulcerogenic properties. Chinese Chemical Letters. 2012 May;23(5):541-4. <DOI $>$.

21. Khan KM, Karim A, Ambreen N, Saied S, Rasheed S, Perveen S, et al. Synthesis of benzoxazoles derivatives: Antiglycation activity. Journal of Pharmacy Research. 2012;5(1):664-5.

22. Medvedev A, Buneeva O, Gnedenko O, Fedchenko V, Medvedeva M, Ivanov $Y$, et al. Isatin interaction with glyceraldehyde-3-phosphate dehydrogenase, a putative target of neuroprotective drugs: partial agonism with deprenyl. In: Parvez $\mathrm{H}$, Riederer $\mathrm{P}$, editors. Oxidative Stress and Neuroprotection [Internet]. Vienna: Springer Vienna; 2006 [cited 2021 Sep 24]. p. 97-103. (Journal of Neural Transmission. Supplementa; vol. 71). $\leq$ URL $>$.

23. Andreani A, Burnelli S, Granaiola M, Leoni A, 
Locatelli A, Morigi R, et al. New isatin derivatives with antioxidant activity. European Journal of Medicinal Chemistry. 2010 Apr;45(4):1374-8. $\leq$ DOI $>$.

24. Kumar $K$, Carrère-Kremer $S$, Kremer $L$, Guérardel Y, Biot C, Kumar V. $1 \mathrm{H}$-1,2,3-TriazoleTethered Isatin-Ferrocene and IsatinFerrocenylchalcone Conjugates: Synthesis and in Vitro Antitubercular Evaluation. Organometallics. 2013 Oct 28;32(20):5713-9. <DOI>.

25. Jarrahpour A, Khalili D, De Clercq E, Salmi C, Brunel J. Synthesis, Antibacterial, Antifungal and Antiviral Activity Evaluation of Some New bis-Schiff Bases of Isatin and Their Derivatives. Molecules. 2007 Aug 7;12(8):1720-30. <DOI>.

26. Saravanan G, Alagarsamy V, Dineshkumar P. Anticonvulsant activity of novel 1(morpholinomethyl)-3-substituted isatin derivatives. Bulletin of Faculty of Pharmacy, Cairo University. 2014 Jun;52(1):115-24. <DOI>.

27. Rane RA, Napahde S, Bangalore PK, Sahu NU, Shah N, Kulkarni YA, et al. Synthesis and Evaluation of Novel Marine Bromopyrrole AlkaloidBased Derivatives as Potential Antidepressant Agents. Chem Biol Drug Des. 2014 Nov;84(5):593-602. <DOI>.

28. Ibrahim S, Elsaman T. Cytotoxic and Anticancer Activities of Indoline-2,3-dione (Isatin) and Its Derivatives. JPRI. 2018 Feb 27;21(2):119. $\leq \mathrm{DOI}>$.

29. Lelyukh M, Havrylyuk D, Lesyk R. Synthesis and anticancer activity of isatin, oxadiazole and 4thiazolidinone based conjugates. Chemistry \& Chemical Technology. 2015;9(1):29-36. $\leq$ URL $>$.

30. Thakur RK, Joshi P, Upadhyaya K, Singh K, Sharma G, Shukla SK, et al. Synthesis of isatin based N1-alkylated 3- $\beta$-C-glycoconjugatedoxopropylidene oxindoles as potent antiplasmodial agents. European Journal of Medicinal Chemistry. 2019 Jan;162:448-54. <DOI>.

31. Quraishi MA, Ahamad I, Singh AK, Shukla SK, Lal B, Singh V. N-(Piperidinomethyl)-3[(pyridylidene)amino]isatin: A new and effective acid corrosion inhibitor for mild steel. Materials Chemistry and Physics. 2008 Dec;112(3):1035-9. $\leq \mathrm{DOI}>$.

32. Prakash CR, Raja S. Design, synthesis and antiepileptic properties of novel 1-(substituted benzylidene)-3-(1-(morpholino/piperidino methyl)2,3-dioxoindolin-5-yl)urea derivatives. European Journal of Medicinal Chemistry. 2011

Dec;46(12):6057-65. <DOI>.
33. Kang I-J, Wang L-W, Hsu T-A, Yueh A, Lee C$C$, Lee $Y-C$, et al. Isatin- $\beta$-thiosemicarbazones as potent herpes simplex virus inhibitors. Bioorganic \& Medicinal Chemistry Letters. 2011

Apr;21(7):1948-52. <DOI>.

34. Medvedev A, Igosheva N, Crumeyrolle-Arias M, Glover V. Isatin: Role in stress and anxiety: Review. Stress. 2005 Jan;8(3):175-83. <DOI>.

35. Kandasamy R, Park SJ, Boyapalle S, Mohapatra S, Hellermann GR, Lockey RF, et al. Isatin downregulates expression of atrial natriuretic peptide receptor $A$ and inhibits airway inflammation in a mouse model of allergic asthma. International Immunopharmacology. 2010 Feb;10(2):218-25. $\leq$ DOI $>$.

36. Bogdanov AV, Zaripova IF, Voloshina AD, Sapunova AS, Kulik NV, Bukharov SV, et al. Synthesis and Biological Evaluation of New IsatinBased QACs with High Antimicrobial Potency. ChemistrySelect. 2019 May 31;4(20):6162-6. <DOI $>$.

37. Blumenthal GM, Cortazar P, Zhang JJ, Tang S, Sridhara R, Murgo A, et al. FDA Approval Summary: Sunitinib for the Treatment of Progressive Well-Differentiated Locally Advanced or Metastatic Pancreatic Neuroendocrine Tumors. The Oncologist. 2012 Aug;17(8):1108-13. <DOI>.

38. Houk BE, Bello CL, Kang D, Amantea M. A Population Pharmacokinetic Meta-analysis of Sunitinib Malate (SU11248) and Its Primary Metabolite (SU12662) in Healthy Volunteers and Oncology Patients. Clin Cancer Res. 2009 Apr $1 ; 15(7): 2497-506$. <DOI $>$.

39. Ristovska N, Anastasova F, Stefova M. N"[(3Z)-1-Acetyl-5-chloro-2-oxo-1,2-dihydro-3Hindol-3-ylidene]thiocarbonohydrazide. Molbank. 2013 Apr 16;2013(2):M798. <DOI .

40. Gassman P, Cue, Jr. B, Luh T-Y. A General Method for the Synthesis of Isatins. J Org Chem. 1977;42(8):1344-8. $\leq$ URL $>$.

41. Klein LL, Tufano MD. Synthesis of substituted isatins. Tetrahedron Letters. 2013

Feb;54(8):1008-11. $\leq$ URL $>$.

42. Mathur G, Nain S. Recent advancement in synthesis of isatin as anticonvulsant agents: a review. Med Chem. 2014;4(4):417-27.

43. Raghavender Reddy M, Nageswara Rao N, Ramakrishna K, Meshram HM. I2-DMSO promoted intramolecular oxidative cyclization of 2-(aryl or alkyl amino)-acetophenones for the synthesis of 
isatins. Tetrahedron Letters. 2014

Aug;55(34):4758-62. <DOI>.

44. Sonawane RP, Tripathi RR. The chemistry and synthesis of $1 \mathrm{H}$-indole-2, 3-dione (Isatin) and its derivatives. International Letters of Chemistry, Physics and Astronomy. 2013;7.

45. Rewcastle GW, Sutherland HS, Weir CA, Blackburn AG, Denny WA. An improved synthesis of isonitrosoacetanilides. Tetrahedron Letters. 2005 Dec;46(50):8719-21. <DOI>.

46. Vandana K, Marathakam A, Thushara B, Rajitha K. A Review on Isatin Derivatives With Diverse Biological Activites. World Journal of Pharmaceutical Research. 2017;6:318-32.

47. Demchuk DV, Elinson MN, Nikishin GI. 'On water'Knoevenagel condensation of isatins with malononitrile. Mendeleev Communications. 2011;4(21):224-5.

48. Khorshidi A, Tabatabaeian K. An ultrasoundpromoted green approach for the synthesis of 3- (indol-3-yl)-3-hydroxyindolin-2-ones catalyzed by Fe(III). J Serb Chem Soc. 2011;76(10):1347-53. $\leq \mathrm{DOI}>$.

49. Elinson MN, Merkulova VM, Ilovaisky AI, Barba $\mathrm{F}$, Batanero B. Electrocatalytic tandem Knoevenagel-Michael addition of barbituric acids to isatins: Facile and efficient way to substituted 5,5'(2-oxo-2,3-dihydro-1H-indole-3,3-

diyl)bis(pyrimidine-2,4,6-(1H,3H,5H)-trione) scaffold. Electrochimica Acta. 2011

Oct; 56(24): 8219-23. <DOI>.

50. Meshram HM, Ramesh P, Sanjeeva Kumar A, Swetha A. An efficient and environmentally friendly DABCO catalyzed Henry reaction of isatins. Tetrahedron Letters. 2011 Nov;52(44):5862-4. <DOI .

51. Yu F, Yan S, Hu L, Wang Y, Lin J. Cascade Reaction of Isatins with Heterocyclic Ketene Aminals: Synthesis of Imidazopyrroloquinoline Derivatives. Org Lett. 2011 Sep 16;13(18):47825. $\leq \mathrm{DOI}>$. 